\title{
„Miejsca” i konteksty
}

Zgromadzone w pracy opisy spotkań ze społecznościami lokalnymi reprezentują zróżnicowany pod względem problemowym i poznawczym materiał będący swoistym kompletem studiów przypadku. Dobór wsi zależał od nieskrępowanej decyzji poszczególnych osób, które świadomie uznały, że właśnie ta konkretna miejscowość stanowiła dla badacza unikatowe studium relacji ludzi z ich środowiskiem życia. W efekcie w opracowaniu zamieszczono dziewięć opisów wsi położonych w różnych regionach przyrodniczych i kulturowych kraju, co tworzy intersujący przegląd różnych uwarunkowań (przyrodniczych, ekonomicznych i społeczno-kulturowych) funkcjonowania lokalnych społeczności oraz ich reakcji na współczesne procesy rozwoju, w tym przede wszystkim kształtowanie się podstaw świadomości i wynikającej z niej tożsamości kulturowej i terytorialnej.

Układ treści, zgodnie z przyjętymi podstawami teoretycznymi badania „miejsc” w myśl Vidalowskiej koncepcji „milieu” („miejsca”) i "genre de vie" (styl życia), odpowiada uporządkowaniu studiów przypadku według położenia ich w obrębie określonych typów krajobrazu Polski. Podstawy przyrodnicze tworzą zatem określony kontekst położenia geograficznego (ogólnego fizycznogeograficznego) oraz topograficznego, czyli szczegółowego, stanowiącego miejscowy układ komponentów środowiska przyrodniczego. W tradycyjnym dla przedstawień zróżnicowania przyrodniczego naszego kraju wyróżnić można pasy krajobrazowe: pobrzeża bałtyckie, pojezierza, niziny, wyżyny, góry (układ północ-południe). Cechy środowiska biotycznego i abiotycznego poszczególnych „miejsc" stanowią zatem pewne obiektywne ramy powstania układu przestrzennego miejscowości, funkcjonowania społecznego, w tym podstaw gospodarczych, a także jeden z ważnych czynników społecznej identyfikacji ze wsią (relacja człowieka i natury).

Z drugiej strony wybrane przez członków zespołu badawczego miejscowości są zróżnicowane pod względem kulturowym, co w każdym przypadku jest wypadkową wielu procesów zachodzących w przeszłości tej dalszej oraz w historii najnowszej. Generalnie różnice kulturowe można opisać odwołując się do zmienności na linii wschód - zachód. Mają one zarówno wymiar materialny odzwierciedlający się np. w architekturze, układach przestrzen-

\section{Marcin Wójcik}

Uniwersytet Łódzki 
nych, użytkowaniu i podziałach ziemi oraz wymiar duchowy związany z szeroko pojętą kulturą, w tym sferą mentalności i zachowań społecznych. Uwarunkowania te tworzą swoisty kontekst położenia kulturowego. Skomplikowana historia Polski wynikająca w dużej mierze z naszego położenia pomiędzy dwoma silnymi państwami (Rosja i Niemcy) oraz równie złożona przeszłość poszczególnych regionów kulturowych wytworzyła pod tym względem duże różnice w obszarach wiejskich Polski, zwłaszcza w regionalnych peryferiach. Charakter „wiejskości”, jej poszczególne wymiary oraz społeczne rozumienie nawiązują w dużej mierze do rozdarcia cywilizacyjnego ukształtowanego w czasach najnowszych, tj. okresie rozbiorowym i późniejszym, zwłaszcza po nadaniu Polsce nowego kształtu terytorialnego (po 1945 r.). Gospodarka wiejska, skład społeczny, mentalność, wartościowanie jest w dużej mierze funkcją dawnych podziałów politycznych, w tym dawnych granic pomiędzy państwami zaborczymi oraz przesunięć ludności po 1945 r. z Kresów i regionów tzw. dawnej Polski do regionów przyznanych nam w wyniku decyzji wielkich mocarstw. W ogólny sposób zróżnicowanie to można pod względem kulturowym przedstawić w podziale na Polskę wschodnią i środkową (regiony wchodzące w skład dawnego zaboru rosyjskiego), Polskę południową (dawny zbór austriacki), Polskę zachodnią „wewnętrzną" (regiony dawnego zaboru pruskiego, później niemieckiego) oraz Polskę zachodnią „zewnętrzną" (regiony przyznane Polsce po II wojnie światowej).

Te dwie „osie” zróżnicowania wiejskiej przestrzeni, tj. przyrodnicza „północ-południe” i kulturowa „wschód-zachód” stanowią dwa ogólne konteksty przedstawień wybranych, interesujących z jakiegoś względu, wiejskich społeczności lokalnych. Listę tę tworzą następujące jednostki osadnicze:
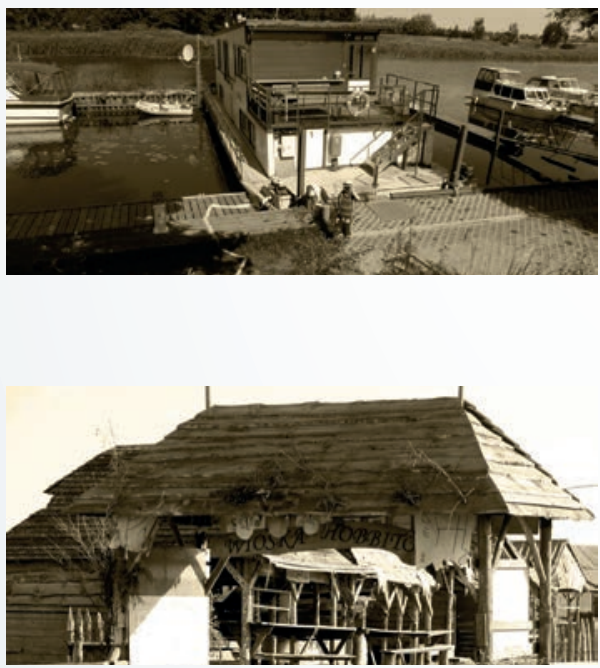

Zuławki - wieś położona na Żuławach Wiślanych, nad rzeką Szkarpawą (pas pobrzeży bałtyckich) z zachowanymi obiektami kultury materialnej Mennonitów - dawnych protestanckich mieszkańców (do 1945 r.). Obszar włączony do Polski w 1945 r.

\section{Sierakowo Sławieńskie - wieś} położona w pasie pobrzeży bałtyckich (Równina Słupska), zasłynęła sprawnie zorganizowaną przestrzenią tematyczną nawiązującej do opowieści o Hobbitach. Na obszarze Pomorza Środkowego, włączonego do Polski w 1945 r. 
Gniewino - wieś gminna położona w pasie pobrzeży bałtyckich (Wysoczyzna Żarnowiecka) oraz w kulturowym regionie Kaszub. Cześć terenu gminy została włączona do Polski w 1945 r., a cześć należała do Polski w okresie międzywojennym. Charakteryzuje się w ostatnich latach wysoką dynamiką rozwoju społeczno-ekonomicznego. Miejsce lokalizacji elektrowni szczytowo-pompowej Żarnowiec.

Głotowo - wieś w położona w pasie pojezierzy (Pojezierze Olsztyńskie). W regionie kulturowym Warmii włączonym ponownie do Polski w 1945 r. (w Polsce w latach 1466-1772). Interesujący układ przestrzenno-architektoniczny z dominantą krajobrazową w postaci Kalwarii Warmińskiej.

Kruszyniany - wieś położona w pasie nizin (Wysoczyzna Białostocka). W regionie kulturowym Podlasia. Charakteryzuje się wielokulturową spuścizną historyczną (dziedzictwo Tatarów, Polaków i Białorusinów).

Domachowo - wieś położona w pasie nizin (Wysoczyzna Kaliska). Ważny ośrodek Biskupizny - regionu folklorystycznego w obrębie Wielkopolski (13 wsi). Charakteryzuje się silną identyfikacją kulturową ludności w oparciu o tradycje związane z dawną przynależnością do dóbr biskupów poznańskich.

Masłomęcz - wieś położona w pasie wyżyn (Kotlina Hrubieszowska). W obrębie gminy Hrubieszów charakteryzującej się bardzo dobrych uwarunkowaniach rozwoju rolnictwa (czarnoziemy). Obecnie wieś buduje swój wizerunek w oparciu o motyw Gotów (biesiady archeologiczne).
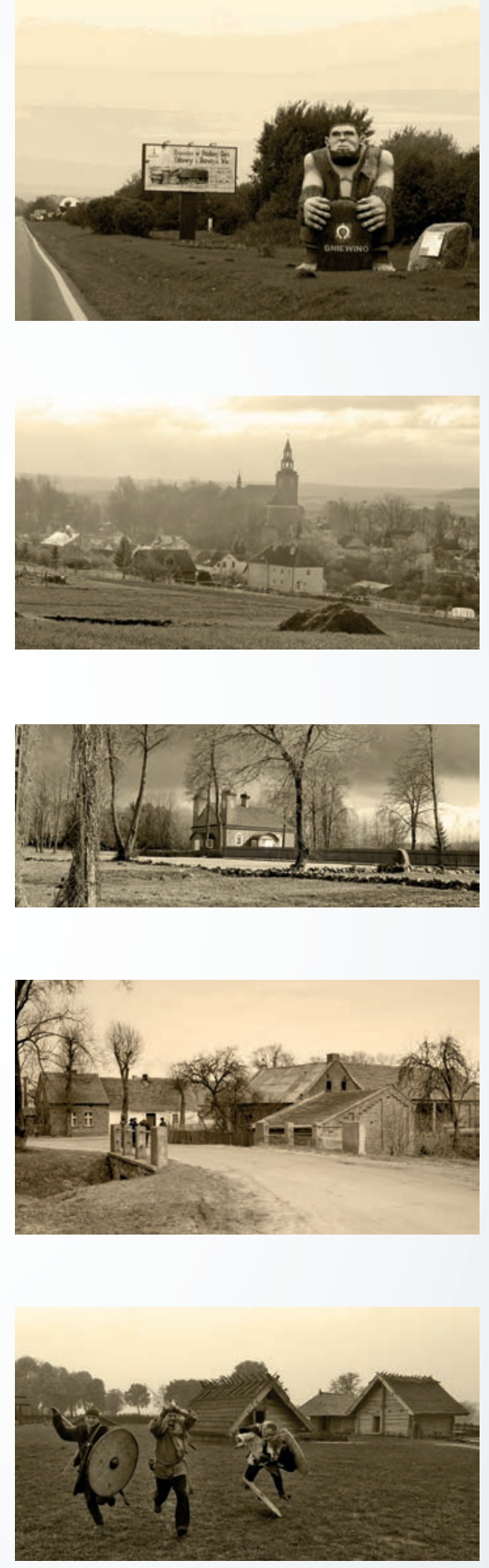

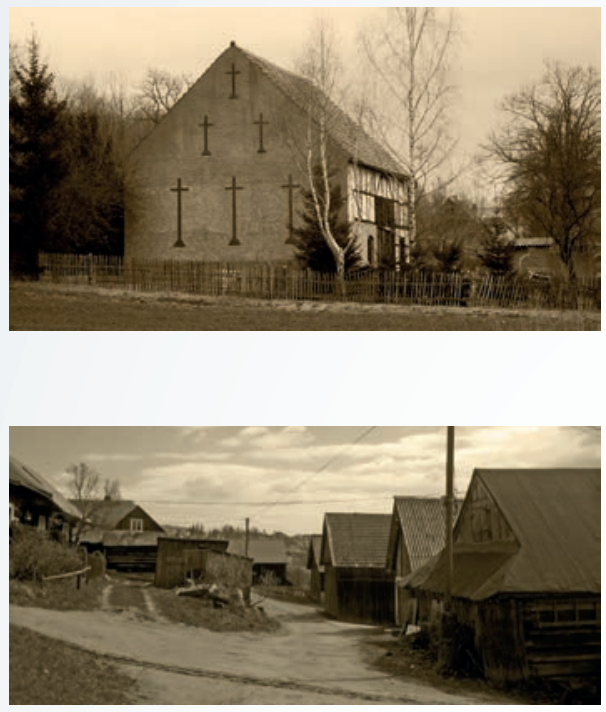

Dobków - wieś położona w pasie gór (Góry Kaczawskie). Społeczność lokalna buduje swą tożsamość w oparciu o specyfikę położenia oraz walorów lokalnych, zarówno przyrodniczych (zróżnicowanie geologiczne i fizjograficzne) jak i o elementy dziedzictwa materialnego. Cześć Dolnego Śląska włączonego do Polski w 1945 r.

Istebna - wieś położona w pasie gór (Beskid Śląski) w regionie kulturowym Śląska Cieszyńskiego (Górale Śląscy). Współczesny rozwój lokalny opiera się na wykorzystaniu walorów przyrodniczych i kulturowych do wzmacniania funkcji turystycznej.

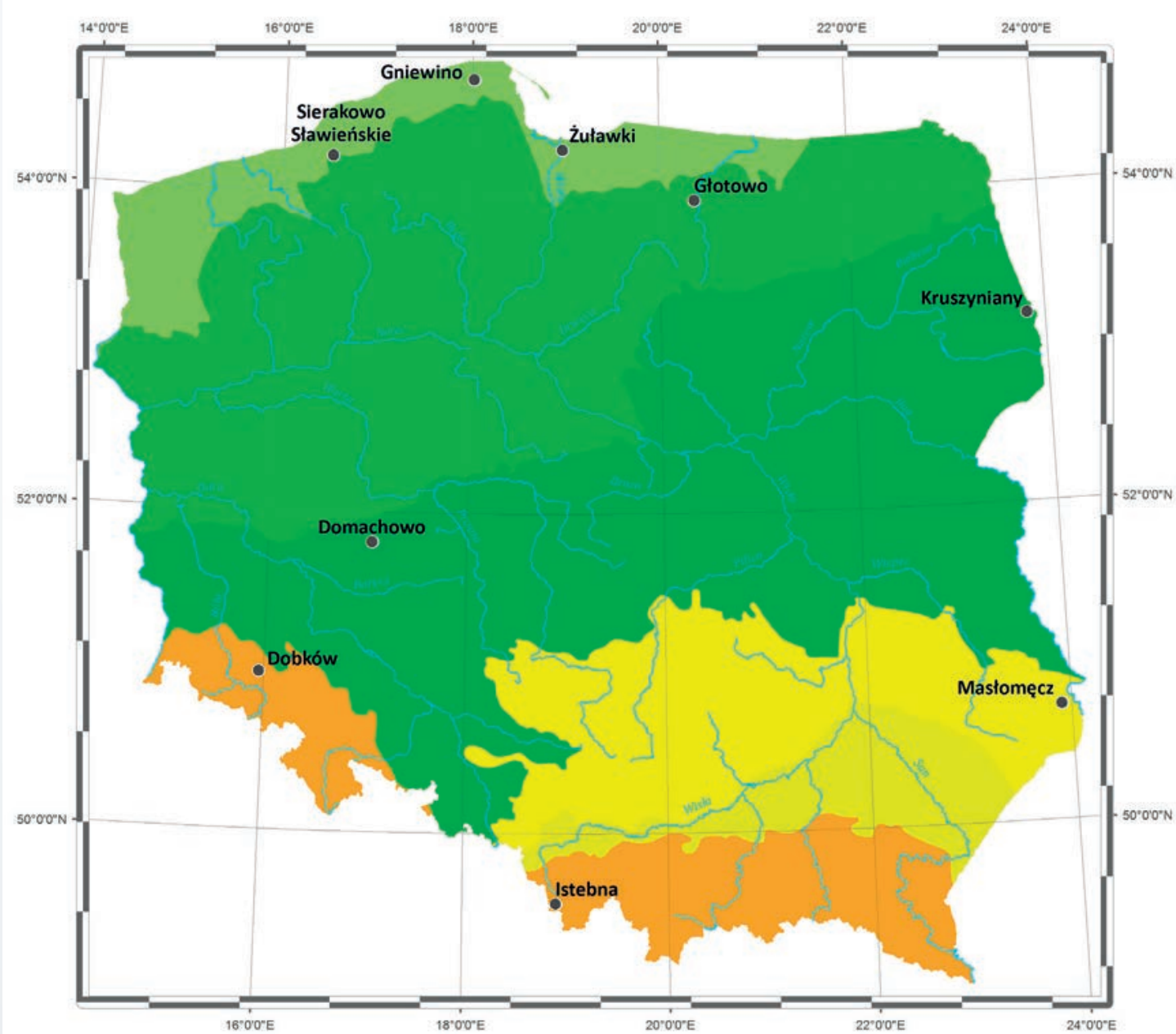

